\section{The Divergent Influence of Social Responsibility on Employee Engagement through the Lens of Marital Status: Evidence from Higher Education Institutions}

\author{
Mei Peng, Low ${ }^{1}$ \\ ${ }^{1}$ Universiti Tunku Abdul Rahman, Departmentof \\ International Business, Bandar Sungai Long, Malaysia
}

Recebimento:

04/10/2019

Aprovação:

09/26/2019

Editor responsável:

Prof. Dr Leire San-Jose

Avaliado pelo sistema:

Double Blind Review

\begin{abstract}
Purpose - This research paper has two purposes. Firstly, it aims to study the influence of social responsibility on employee engagement in a non-business setting, particularly higher education institutions. Internal Corporate Social Responsibility and Perceived Roles of Ethics and Social Responsibility were used to measure the social responsibility aspect. Secondly, the study further explores the difference between two heterogeneous groups of academics.
\end{abstract}

Design/methodology/approach -A quantitative approach and nonprobability judgmental sampling method were used in this research. A self-administered questionnaire containing the respondents' demographic information and the main constructs of the research framework was distributed among the respondents targeted. Partial least squares structural equation modelling was used to assess the predictability of the model and a multi-group analysis was conducted to examine the differences between the non-married and married academics.

Findings - The findings reveal that Perceived Roles of Ethics and Social Responsibility and Internal Corporate Social Responsibility are significantly related to academics' Employee Engagement. The conclusion is that ethics and social responsibility have a similar influence in a non-business setting, such as a higher education institution. An insignificant result is obtained for the two heterogeneous groups of non-married and married academics.

Originality/value - This research paper provides informative insights on the roles of ethics and social responsibility in a non-business setting, i.e., higher education institutions. It also complements the understanding of their insignificant influence on married and non-married academics. This serves as good information for higher education institutions' administrators for devising alternative means to improve academics' engagement in the workplace.

Keywords - ethics and social responsibility, Internal Corporate Social Responsibility, employee engagement, academics, Multi-group analysis

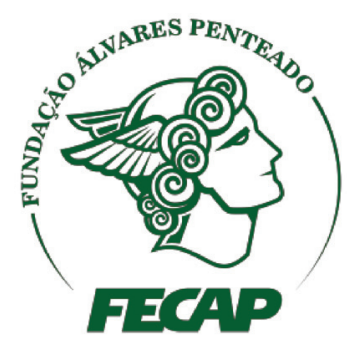

Revista Brasileira de Gestáo
de Negócios

DOI: $10.7819 /$ rbgn.v22i2.4046 


\section{Introduction}

"Beyond profit and being socially responsible" is often the tagline related to Corporate Social Responsibility (CSR) (Hortyn, 2019). CSR has been discussed worldwide in business organisations since the 1950s and it has been recognised as important. Nowadays, CSR is also receiving increasing attention due to the everchanging business environment. However, its roles in the non-business context such as the education sector are still underexplored. The United Nations Educational, Scientific and Cultural Organisation (UNESCO) stated that education is an approach to endow both children and adults to become active participants in the transformation of society. Amid the education process, qualities, mentalities, and practices empower individuals to learn in a world characterized by variety and pluralism. Education and academics have a novel part to play in imparting knowledge and shaping the future of the general public. Recently, Crowther and Seifi (2018) attempted to further explain CSR and its role in sustainability. They pointed out that CSR has a cascading effect stemming from its societal impact through the education sector. The particular definition of CSR in the education sector motivates this study. The research also explores the Life Cycle Model through marital status for a comprehensive understanding of the impact of ethics and social responsibility on academics' engagement at Malaysian higher education institutions.

This paper bridges the gap between ethics and social responsibility and higher education institutions. The gap could be closed by addressing the questions of "What is the role of social responsibility in higher education institutions?" and "How does it affect academics?" The research paper endeavours to understand the protagonists of ethics and social responsibility in the education sector through the parameters of Perceived Role of Ethics and Social Responsibility (PRESOR) and Internal CSR practices and their influence on academics' employee engagement. Employee engagement is construed as the ultimate outcome of ethics and social responsibility. The findings of this research complement existing knowledge of ethics and social responsibility in the non-business setting, particularly the education sector. The research paper is structured into the following sections: background of the study, literature review, research gap, theoretical framework, research framework and hypotheses, research design and methodology, data analysis and findings, conclusion and discussions, theoretical and managerial implications, limitations and directions for future research.

\section{Background of the Study}

With Malaysia’s transition to a knowledgebased economy, policymakers have more specifically linked the development of the higher education sector to the requirements of economic growth. The Malaysian government is aspiring to deliver a well-prepared, skilled, trained, and proficient workforce that strives for economic growth and is resilient to rapid change. This effort is evidenced in the amendment to the Education Act in 1995, which was followed by the implementation of the Private Higher Education Act in 1996. Consequently, higher education institutions are springing up like mushrooms after rain. According to the Ministry of Higher Education (2017), Malaysia had 20 public universities and 43 private universities, 31 private university colleges and 9 foreign university branches as of 2015 .

Meanwhile, the Industrial Revolution 4.0 (IR4.0) has also given some new drive to the higher education sector in the form of multidisciplinary integration embracing the elements of innovation and technology. Higher education institutions are required to re-think the structure of their academic programs with pedagogy that is more flexible and focussed on practical, competencybased learning with new systems of accreditation and certification.

The massive development and the aggressive competition in the education sector 
coerce higher education institutions into strategizing their institutions' directions to compete and survive in this intense state of rivalry. In this regard, academics are required to carry out bigger and more tasks that go beyond their conventional roles of imparting knowledge to the future generation. Academics' responsibilities are expanded to include heavy teaching loads, community-based research, requesting research opportunities, sourcing research grants, and providing professional services, all of which may constitute an overwhelming set of role expectations (Bochenek, Kingston-Mann \& Sieber, 2002). Recently, Cadez, Dimovski and Zaman Groff's (2017) research findings highlighted the reduced teaching quality of universities as a result of increased pressure for research publications to meet worldwide university ranking objectives. Jing (2008) added that the stressful conditions experienced by academics lead to misery, resulting in vulnerability and behavioural problems such as depression, fatigue, inefficiency, absenteeism, and much more. This situation explains the reduced performance in their core teaching tasks. This could negatively affect national competitiveness due to the inability of academics to produce qualified graduates. In view of the discussion of ethics and social responsibility being widely accepted in business organisations, this research aims to examine its impact among the academics in higher education institutions in terms of them carrying out their multiple roles yet displaying a high level of employee engagement.

\section{Literature Review}

\section{I Ethics and social responsibility}

For the past few decades, there has been growing concern paid to the ethics and social responsibility dimensions of businesses. Despite the attention given, the degree of focus on the ethics and social responsibility dimension varies according to the country environment. As a result, there is a wide divergence in the level of importance given to ethics and social responsibility. The divergence is mainly attributed to the stage of national economic development, cultural standards, legal/political structure, and business conduct expectations (Wotruba, 1997). Despite the possibilities of similarities in terms of definition between these two concepts, Carroll (1999) explained that the new definition that emerged in the 1980s is due to more available progressive empirical research. The disparity includes stakeholder theory, stakeholder management, corporate social responsibility, corporate social performance, corporate citizenship and business ethics as well as corporate social responsiveness, which emerged recently. Commonly, ethics is described as the vital principle that generates actions to prevent considerable damage to others, when an individual or group has the chance to do such damage so for their own benefit (Boddy, 2011). Social responsibility entails a moral principle framework, which advocates that an entity, be it an individual or organisation, has an obligation to work for the benefit of society at large. Every individual has the duty to behave in a manner that strikes a balance between the economy and society. This is considered as social responsibility. An individual's moral standard is based on the individual's perception as to whether they can severely hurt or benefit another individual (Churchill, 1982). The individual's perception relates to their perception of ethics and social responsibility (PRESOR) while at work carrying out their tasks. Singhapakdi, Vitell, Rallapalli and Kraft (1996) claimed that it is crucial for managers to have the right level of perceived ethics and social responsibility for business success and so that they behave in an ethical and socially responsible manner. Yin, Singhapakdi and Du (2016) claimed that research on PRESOR is scarce. It is thus worthwhile to explore the PRESOR research. Hence, PRESOR is examined in this research to investigate its influence on Internal CSR practices, which represents the stakeholder aspect of CSR, in the education sector. 


\subsection{Perceived Roles of Ethics and Social Responsibility (PRESOR)}

Based on the structural belief system of a society, perceptions are social phenomena that constitute the mental models of an individual. Empirical studies have further explained that an individual must first perceive ethics and social responsibility as important for each endeavour before they will act in an ethical and socially responsible way (Vitell, Ramos, \& Nishihara, 2010). From the standpoint of an organisation, the management's values and beliefs would serve as a top-down guide for recognising and evaluating social issues which are important to the stakeholders. The appreciation of the ethics and social responsibility obligation by management amplifies the effectiveness of the organisation. The pioneering research that developed the measurement scale for PRESOR was done by Singhapakdi (1999). In his measurement scale for PRESOR, general measures were included relating to the importance of ethics and social responsibility and them being the determinants of an organisation's overall effectiveness and efficiency. Past studies have further reinforced the idea that PRESOR scales consist of three important social dimensions: the stakeholder view, the compatibility view, and the stockholder view (Axinn, Blair, Heorhiadi \& Tharch, 2004; Shafer, Fukukawa \& Lee, 2007). Shafer et al. (2007) clarified that the stakeholder view reflects the importance of ethics and social responsibility in relation to any organisation's survival and success. Shafer et al. (2007) complemented the stakeholder view by indicating the broader and long-term perspective of corporate obligations, which corresponds to Singhapakdi et al.'s (1996) long-term gains. As for the compatibility view, Shafer, et al. (2007) described it as indicating the compatibility of ethics and social responsibility with business success. According to them, the stockholder view reveals a constrained and fine aspect of corporate obligations focusing on profitability and obligations. This stockholder view is analogous to Singhapakdi et al.'s (1996) short-term gains. Conceptually, this view reflects the individual's tendency to believe ethics and social responsibility is also important in achieving short-term gains.

Drawing from the limited research on PRESOR in the non-business context and considering the challenges encountered by higher education institutions, this study aims to examine the impact of PRESOR on Internal CSR practices along with its influence on employee engagement among academics.

\subsection{Internal Corporate Social Responsibility (CSR)}

A study conducted by UN Global Compact-Accenture in 2010 reported that 93\% of 766 CEOs acknowledged CSR as an important component for their organisation's future success (https://microsite.accenture.com/ sustainability/research_and_insights/Pages/ ANew-Eraof-Sustainability.aspx, retrieved on 30 August 2019). Superior CSR requires an organisation's engagement and commitment to various stakeholders. This is consistent with Low's (2019) finding of the increasing importance of CSR among stakeholders since the late 2000s.

Freeman (1984) explained that the stakeholders of a firm include those that affect or are affected by the organisation's goals. The extensive literature offers various classifications in order to outline the concept. Some of the most commonly used classifications are primary and secondary stakeholders (Clarkson, 1995; Freeman, 1984); external and internal stakeholders (Verdeyen, Put \& Buggenhout, 2004); contracting and public stakeholders (Charkham, 1994); voluntary and involuntary stakeholders (Clarkson, 1995); internal, external and societal stakeholders (Werther \& Chandler, 2006); internal, external, societal and environmental stakeholders (Lozano, 2015); and primary social, secondary social, primary non-social and secondary non-social stakeholders (Wheeler \& Sillanpaa, 1997). Lozano and Prandi (2005) labelled CSR towards employees as human 
rights. The authors explained that there are rising numbers of organisations that relate human rights to their CSR strategy and include them as a resource to measure and evaluate their CSR. Of the multiple groups of stakeholders, employees are considered as the internal stakeholders who are directly involved in the continued existence of an organisation. In regard to the terminology, due to the nature of CSR activities relating to the well-being of employees, the term Internal CSR (Turker, 2009a) is adopted for this study. Turker (2009a) instigated the research of internal CSR undertakings and developed the parameters for Internal CSR. Turker (2009a, 2009b) found that Internal CSR undertakings are activities directly related to employees' physical and psychological working conditions. A pharmaceutical study was conducted in Germany by Mory, Wirtz and Göttel (2016) using Turker's (2009a, 2009b) definition of Internal CSR to measure its impact on employees' organisational commitment. The five dimensions utilised in Mory et al.'s (2016) research pertaining to Internal CSR practices are Training and Development, Human Rights, Health and Safety, Workforce Diversity, and Work-Life Balance. In view of the predicaments encountered by academics in the intensely competitive environment and the tremendous pressure, it is deemed timely to study the impact of Internal CSR practices in the education sector. For this research, the five dimensions developed by Turker (2009a, 2009b) and adopted by Mory et al. (2016) are used to gauge its impact among academics' employee engagement. The five dimensions of Internal CSR adopted are further explained in the subsequent sections through a funnel approach that fits into the current research context.

\subsection{Training and development (TD)}

Training and development is a crucial element to extend the informational base and skills of employees. Yet, not many business organisations are willing to invest in view of the potential cost entailed. Training and development features among organizational efforts to carry out CSR duties. Investments in training and development will be repaid through employees' enhanced capability and performance. Through effective learning, employees can increase their productivity and it results in an improvement of job satisfaction and commitment towards their organisation (Halpin, Curtis, \& Halpin, 2015). The positive outcome would certainly assist employees to perform better and consider new elements that help them to excel in their jobs. Hence, training and development helps organisations to sustain firm competitiveness. In addition, it creates an encouraging work environment and greater commitment from the employees (Neacşu, 2015). Employees may gain more fulfilment regarding their organisation as they feel they are being appreciated and valued by their firm. It is a win-win situation. The training and development element is particularly important in the educational setting. In the current fast-changing landscape, every day increased development is achieved, especially derived from the advancement of information and communications technology. Academics constantly keep themselves abreast with the changing environment and further equip themselves with new knowledge. Recent research by Mone and London (2018) claimed that training and development could help to increase employee performance and thereby produce engaged employees.

\subsubsection{Human rights (HR)}

Over the past decades, the human rights aspect has become essential, with many organisations distinguishing themselves as human rights associations. Past research (e.g., Joscelyne, Knuckey, Satterthwaite, Bryant, Li \& Brown, 2015) has suggested that business organisations have to take charge of all circumstances adequately, speedily, and decently. In fact, all organisations should react to all situations of discrimination by acting quickly, addressing complaints within the workplace, and communicating with the 
complainant regarding the issues faced. This is part of the Internal CSR dimension. In the education sector, academics are regarded as educators who have expertise knowledge. The Internal CSR practices and findings obtained from the education sector would certainly offer some interesting insights.

\subsubsection{Health and safety (HS)}

Working environments certainly play a role in employees' productivity. It is the employer's obligations to provide for the health and safety of all individuals in the working environment (Gibbins \& MacMahon, 2015). A safe and conducive working environment can improve employees' productivity and organisational commitment. The Internal CSR dimension includes establishing a safe and protected workplace for employees. Kunyk, Craig-Broadwith, Morris, Diaz, Reisdorfer and Wang (2016) added that providing a healthy and safe working environment is the easiest yet most ideal approach to retain employees and enhance their organisational commitment in order to maximize profitability. This research focusses on academics in higher education institutions, and the expectations of academics on the issue of health and safety is overall greater than that of the general public. The educational level of academics contributes to their reactions to any form of working environment that is not abiding by the Occupational Safety and Health Administration (OSHA). As such, it would be of interest to study the element of Health and Safety as part of higher education institutions' Internal CSR practices.

\subsubsection{Workforce diversity}

Workforce diversity denotes the disparity of employees within the same organisation. Disparities can be in the form of race, ethnicity, culture, age, identity, subjective style, residency, hierarchical level, education, and others (Enehaug, Helmersen \& Mamelund, 2016). Organisations should embrace diversity in order to enrich ideas yet carefully handle and deal with the diverse work environment. In a similar vein, diversity also refers to how employees see themselves as well as how they see others. The ability to handle a diverse workforce in the working environment should be cultivated in any organisation, specifically in problem-solving and decision-making (Grivastava \& Kleiner, 2015). In fact, a study showed that a diverse workplace could increase employees' organisational commitment and enhance their employee engagement (Adu-Febiri \& Quinless, 2010). This justifies its inclusion in the Internal CSR measure. According to the Malaysian Qualifications Framework (MQF), higher education institutions are assessed in term of quality of teaching and learning. Among others, workforce diversity is one of the criteria for obtaining the QS ranking. Hence, the workforce diversity element in Internal CSR is deemed appropriate for the current research setting.

\subsubsection{Work-life balance}

The business world has started to acknowledge the importance of work-life balance as a means to retain performing employees. Russo, Shteigman and Carmeli (2016) revealed that work-life balance is one of the significant elements in promoting employees' engagement for it allows spaces and times for work and non-work life. Frequent work-related interruptions impact employees' behaviour and their performance in their job. This is consistent with Polkowska's (2016) finding that when work encroaches on personal time this decreases employees' work fulfilment and reduces employees' engagement. Kaliannan, Perumal and Dorasamy (2016) added that a good work-life balance leads to higher employees' engagement at work, resulting in better performance and employees ultimately staying with firms. In fact, Kuron, Lyons, Schweitzer and Ng's (2015) research suggested that millennials value work-life balance over meaningful work and job progression. Regarding the current research context of education, Kleinhans, Chakradhar, Muller and Waddill's (2015) research stated that 
millennials form the generational composition of higher education institutions as workplaces that offer flexibility and work-life balance. The component of work-life balance within Internal CSR practices should bear some significant value in the current research setting.

\subsection{Employee engagement}

The concept of employee engagement emerged in the late 1920s as a human resource component. Generally, employee engagement is understood as a vast construct that covers multiple facets of human resource management. Currently, there is no single and generally recognised definition of the term employee engagement due to its nature, which is affected by many factors involving both emotional and rational ones pertaining to work and the overall work experience. Nevertheless, Kompaso and Sridevi (2010) mentioned that the construct of employee engagement is based on earlier fundamental concepts such as job satisfaction, employee commitment and organisational citizenship behaviour. Many researchers have attempted to define employee engagement according to contexts of organisational behaviour. For instance, Robinson, Perryman and Hayday (2004) defined employee engagement as a range of positive attitudes exhibited by the employee towards his or her organisation. Vance (2006) defined employee engagement by emphasising the inseparable relationship with employer practices. The author provided a more detailed description of employee engagement as the outcome of personal attributes such as knowledge, skills, abilities, temperament, attitudes and personality; the organisational context, which includes leadership, physical setting and social setting; and human resource practices that directly influence individual, process and job performance. Subsequently, Macey and Schneider (2008) defined employee engagement as a desirable state that consists of an organisational purpose and relates to involvement, commitment, passion, enthusiasm, focus and effort. Engagement involves passion and obligation from the employee, which translates into his or her willingness to invest in him or herself and further increases discretionary efforts to help the organisation meet its goal, which goes beyond basic satisfaction with the employment arrangement or basic loyalty to the organisation (Macey \& Schnieder, 2008; White, 2008). Thus, the full engagement spectrum is achieved through maximum job satisfaction and the highest level of job contribution. This explanation covers attitudinal and behavioural aspects that are adopted for this research.

\subsection{Life-cycle model and marital status}

Social science research studies the behaviour of society and every individual in society is affected by their respective life-cycle changes. Drawing from the generic concept of the Life-Cycle Model, there is interdependency between the labour force participation rate and life-cycle marital status. A study conducted by Van der Klaauw (1996) revealed that there is a strong relationship between female labour force participation and marital status. This finding is supported by economic theories of marriage, whereby there is a strong correlation between a female's participation in the labour market and utility gains from marriage (Van der Klaauw, 1996). A decade later, Benson (2006) reinforced the correlation between the life-cycle model and employee participation by explaining types of activities in an organisation that influence employees' commitment and turnover intention. The discussion of the life-cycle model was later expanded from the micro to the macro level, i.e., an organisation's life cycle. This is evidenced by Su, Baird and Schoch's (2015) research to identify an effective management control system for organisations after uncovering the association between types of control and employees' organisational commitment. Against the backdrop of the on-going discussion of the relationship between life cycle and labour force participation rate, this research attempts to study a similar effect in the context of ethics and social 
responsibility and their influences in the higher education setting.

\section{Research Gap}

The aforementioned discussion indicates that there is a dearth of CSR research conducted in the context of ethics and social responsibility from the academics' perspective. This study is timely due to the development and change of the educational landscape in Malaysia. As such, it would be of interest to expand the ethics and social responsibility research to the education sector. With reference to the endless forces of changes, the life-cycle model is also being included by investigating the marital status of the academics. The lack of existing studies opens up an avenue for research to bridge the gap by adding more findings on ethics and social responsibility in the non-business setting. This research adds value by re-visiting the life-cycle model through the lens of marital status.

\section{I Theoretical framework and its contribution}

In every social science study, the creditability of the findings is subject to there being a strong theoretical framework, a robust research methodology, and a reliable and valid result. Creswell and Creswell (2017) highlighted that in quantitative research a theory is used deductively and features at the beginning of the research plan. The inclusion of a theory is to test or verify it. The same authors added that a study to advance a theory commonly collects data to test it, and reflects on the confirmation of the theory through the results in the study. The theory becomes a blueprint for the entire study and guides an organising model for the research questions or hypotheses for the data collection procedure (Creswell \& Creswell, 2017).

Frequently, there is no standalone theory for a particular field of study in social sciences. For the current research, the theory underpinning the research framework is borrowed from the organisational theory. The organisational theory features approaches practised in organisational analysis whereby organisations are defined as social units of people that are structured and managed to meet a need or to achieve collective goals. Social Exchange Theory and Stakeholder Theory are the two core theories adopted to study the subject matter. A higher education institution is construed as a social organisation that consists of a unit of people structured to offer and impart knowledge. The units of people referred to in this context are the employees. In light of the understanding that organisations are made up of employees, Social Exchange Theory is examined in this study. As ethical and social responsibility is the focal point of the research, Stakeholder Theory was also utilised to form the theoretical basis of the research.

Blau (1964) developed and defined Social Exchange Theory as a social exchange relationship without specified obligations in which some favours produce diffuse future obligations, and yet are not precisely defined, and the nature of the return is not negotiable but must be left to the discretion of whoever provides it, and what the parties exchange is ambiguous. The current study discusses how ethics and social responsibility affect employees' engagement, highlighting the essence of reciprocity in Social Exchange Theory. The discussion of ethics and social responsibility commonly involves Stakeholder Theory since the stakeholder view reflects the significance of ethics and social responsibility to any organisation's survival and success (Shafer et al., 2007). Also, an organisation's stakeholders are the individuals or groups who are directly affected by its operations and decisions and thereby candidates for either potential benefits or harm (Elango, Paul, Kundu \& Paudel, 2010).

For the current context of higher education institutions, it is challenging to pin down specific processes and outputs owing to the nature of the objective of their formation. The various changes in Malaysia such as the transition toward a knowledge-based economy and the evolution 
of the Industrial Revolution have presented a complex environment for the higher education sector. For this very reason, it is important for academics to be motivated to go above and beyond their formal job responsibilities, and to be engaged in their roles. The previous discussion highlighted the absence of a standalone theory in the education sector and the rationale behind adapting theories from organisational approaches. In this context, Social Exchange Theory is a theoretical explanation for employee engagement, while Stakeholder Theory explains the employee, i.e., the academic in the higher education sector, from the ethics and socially responsible perspective. This study contributes to the existing literature and knowledge on the applicability of Social Exchange Theory and Stakeholder Theory beyond the business setting.

\section{Research Framework and Hypotheses Development}

Against the background described, the following research framework is developed to operationalise the study:



Figure 1. Research Framework

Scholars (e.g., Roeck \& Maon, 2016; El Akremi, Gond, Swaen, Roeck \& Igalens, 2015) have proposed that when employees perceive the importance of ethics and social responsibility, they tend to behave more socially responsible and by this means display positive employee engagement in assisting their organisations to accomplish their social and economic goals. Singhapakdi et al. (1996) also claimed that the perceived importance of ethics and social responsibility is likely to be a determinant for organisational effectiveness among stakeholders. This is interpreted as the perceived importance of ethics and social responsibility potentially being a factor of actual behaviour and thereby a determinant of organizational success through positive employee engagement. In addition,
Gupta and Sharma (2016) suggested that the alignment of corporate values with employee ethics has a significant influence on employee engagement. Based on this explanation, the following hypothesis is developed:

\section{$\mathbf{H}_{1}$ - There is a positive relationship between perceived roles of ethics and social responsibility and employee engagement.}

CSR captures an organization's pledge to and engagement with multiple stakeholders, while Internal CSR practices focus particularly on the primary internal stakeholder, namely the employees. As Internal CSR practices cover the well-being of employees, CSR in an organization is believed to produce the Matthew Effect. 
Employee engagement is the focus of the present study as Internal CSR fosters a chain of positive employee outcomes (Aguinis \& Glavas, 2012; Bauman \& Skitka, 2012). Many scholars (e.g. Roeck, Marique, Stinglhamber \& Swaen, 2014; Valentine \& Fleischman, 2008; Zhu, Yin, Liu \& Lai, 2014) have agreed that positive employee attitudes entail higher job satisfaction and enhanced organizational commitment (Collier \& Esteban, 2007; Dögl \& Holtbrügge, 2014; Farooq, Payaud, Merunka \& Valette-Florence, 2014; Hofman \& Newman, 2014; Mueller, Hattrup, Spiess \& Lin-Hi, 2012), which is displayed in employee engagement towards the organisation. Kompaso and Sridevi (2010) stated that employee engagement is a stronger predictor of positive organizational performance as it relates to profitability through higher productivity, sales, customer satisfaction and employee retention. Recent research conducted by Potdar, Guthrie, Gnoth and Garry (2018) suggested the significant influence of positive external and internal CSR practices on employee engagement. As such, the following hypothesis is formulated:

\section{$\mathbf{H}_{2}$ - There is a positive relationship between Internal CSR and employee engagement.}

The life course perspective emphasizes that the timing of role transitions creates an important social context that influences: (1) the ease with which new roles are incorporated into one's identity, (2) the normative status and social acceptance of new roles, (3) the resources that are available to adjust to the new role and, consequently, (4) the effect of these roles and transitions on well-being (Elder, 1985). The objective of the insertion of the life course perspective is to advance and complement the understanding of the role of ethics and social responsibility among married and non-married employees instead of using a blanket conclusion for all. From the life course perspective, the following hypotheses are formed:
$\mathbf{H}_{3}-$ There is a significant difference in the perceived roles of ethics and social responsibility in employee engagement between non-married and married employees.

$\mathbf{H}_{4}$ - There is a significant difference in Internal CSR and employee engagement between non-married and married employees.

\section{Research Design}

This is a cross-sectional study in which the data-gathering process was carried out at only one point in time from a sample of the population in the fastest and least expensive manner (Sekaran $\&$ Bougie, 2010). The non-probability judgemental sampling method was used to collect responses from targeted respondents. The data were collected through an intercept survey using a selfadministered questionnaire in private universities located in Peninsular Malaysia. The G* power 3.1 (Faul, Erdfelder, Lang \& Buchner, 2007; Faul, Erdfelder, Lang \& Buchner, 2009) software was used to compute the sample size required to meet the statistical requirement for testing the proposed research model. Based on a power set at $80 \%$ (Gefen, Rigdon \& Straub, 2011), $f=0.05$ (small), $\nabla=0.05$, and number of predictors $=2$, the sample size required was 210. A total of 300 copies of the questionnaire were distributed. 212 sets of complete usable questionnaires were successfully collected, yielding a response rate of $70.7 \%$. The sample size is deemed sufficient for three main reasons. Firstly, the sample size exceeded the minimum threshold of 210 based on the $G^{*}$ Power 3.1 calculation. Secondly, the minimum power required in social and behavioural science research is typically 0.8 . Thirdly, previous studies (e.g., Akter, D’Ambra \& Ray, 2011; Reinartz, Haenlein \& Henseler, 2009) have identified a threshold of 100 samples for PLS-SEM analysis. Hence, a sample size of 212 returning complete usable questionnaires would be considered as adequate for the statistical analysis. 
The self-administered questionnaire includes three sections. Section A covers the respondents' demographic information, while Section B includes statements to gauge the respondents' perceptions on PRESOR (the item was adapted from Singhapakdi et al., 1996) and Internal CSR [the items were adapted from Turker (2009a, 2009b)] and Section C contains information relating to Employee Engagement adapted from Macey and Schneider (2008). The items in Section B and C used an ordinal scale i.e., ranking the respective statement based on the respondents' level of agreement. For this research, a five-point Likert scale ranging from $1=$ strongly disagree to $5=$ strongly agree was used.

\subsection{Research Methodology}

The data collected were analysed with the help of partial least squares structural equation modelling (PLS-SEM) in Smart PLS. There are three main reasons for using PLS-SEM in this research. Firstly, the Internal CSR construct is operationalised at a higher level of abstraction, i.e., hierarchical component models (HCMs) (Lohmöller, 1989) that involve testing secondorder constructs. An ensuing HCM would include a general Internal CSR construct with five sub-constructs that capture different concrete measures of Internal CSR, such as Human Rights, Health and Safety, Training and Development, Work-Life Balance and Work Diversity. These more concrete, lower-order constructs form more abstract Internal CSR practices for parsimony purposes. Secondly, the research objectives include both confirming the theory and exploring the theory based on total variance. Confirming the theory forms the basis for endorsing the underpinning Stakeholder Theory and Social Exchange Theory to explain the roles of ethics and social responsibility in employee engagement. Thirdly, PLS-SEM has emerged as a prevalent statistical method due to its ability to handle complex models that involve a moderator, as in the current research setting, where life course perspectives, namely marital status, are included in the study. Based on these brief explanations, PLS-SEM was employed to perform the statistical analysis.

\subsection{Multi-group analysis}

This research aims to study the role of ethics and social responsibility in employee engagement in two observed heterogeneity samples. These two observed heterogeneities are non-married status and academics. The path coefficients generated from these two samples may be numerically different and the concern lies in whether the differences are statistically significant. As such, multi-group analysis (MGA) is performed to test the influence of ethics and social responsibility on employee engagement. Eberl (2010) pointed out that MGA is especially useful for tests of discrete heterogeneity samples.

The first step of MGA involves dividing the data into two subsamples according to the observed heterogeneity (e.g. non-married and married status) to estimate their respective path model. The measurement invariance would be established therein. Subsequently, the analytical tests go on to assess whether the path coefficients of the two subsamples of a particular relationship differ significantly. The bootstrapping procedure recommended by Henseler (2007) was used to test the significance of the group differences. Henseler, Ringle and Sinkovics (2009) explained that this approach is distribution free and better fits into PLS path modelling compared to t-test procedures with their inherent distributional assumptions. They added that testing the difference is only required if both coefficients are significant and in the same direction. The present study conducted the MGA based on these authorities' recommendations.

\subsection{Common method variance}

This research is interested in uncovering the academics' perceptions of the roles of ethics and social responsibility in their employee 
engagement, using data from a self-reported questionnaire. This approach is often subject to the issue of common method variance (CMV). To mitigate and estimate the effect of CMV, different procedural and statistical solutions that are in line with Podsakoff, MacKenzie, Lee and Podsakoffs (2003) recommendations were considered. In terms of the procedural solution, the measures of the constructs are collected from different sources and there is a different scale adopted for different constructs. As for the statistical solution, Harman's one-factor test was carried out for all latent variables in the model. No single factor explained a substantial amount of covariance. As such, it is unlikely that CMV hampered the validity factor test. It is concluded this research does not suffer from CMV.

\section{Data Analysis and Results}

\section{I Respondents' profile}

Table 1 reports that the majority of the respondents are female, accounting for $52.8 \%$, while $47.2 \%$ are male. Most of the respondents (50.9\%) are under 35. In terms of marital status, more than half are single, i.e., non-married. Chinese respondents are dominant among other ethnicities, accounting for $43.4 \%$, followed by Malays (32.1\%) and Indians (23.1\%). Regarding years of service, $44.8 \%$ of the respondents have been working at their current universities for 4 years and less, $37.7 \%$ have been working at them for 5 to 10 years, and less than 20\% have been working for more than a decade at their current universities.
Table 1

Respondents' Profile

\begin{tabular}{|c|c|c|}
\hline Profile & Sample $(\mathrm{N}=212)$ & Percentage \\
\hline \multicolumn{3}{|l|}{ Gender } \\
\hline Female & 112 & $52.8 \%$ \\
\hline Male & 100 & $47.2 \%$ \\
\hline \multicolumn{3}{|l|}{ Age } \\
\hline$<35$ year old & 108 & $50.9 \%$ \\
\hline $35-44$ & 65 & $30.7 \%$ \\
\hline $45-54$ & 29 & $13.7 \%$ \\
\hline$>54$ & 10 & $4.7 \%$ \\
\hline \multicolumn{3}{|l|}{ Ethnic } \\
\hline Malay & 68 & $32.1 \%$ \\
\hline Chinese & 92 & $43.4 \%$ \\
\hline Indian & 49 & $23.1 \%$ \\
\hline Others & 3 & $1.4 \%$ \\
\hline \multicolumn{3}{|l|}{ Marital Status } \\
\hline Non-married & 109 & $51.4 \%$ \\
\hline Married & 103 & $48.6 \%$ \\
\hline \multicolumn{3}{|l|}{ Years of service } \\
\hline 4 years and less & 95 & $44.8 \%$ \\
\hline 5-10 year & 80 & $37.7 \%$ \\
\hline $\begin{array}{l}10 \text { years and } \\
\text { above }\end{array}$ & 37 & $17.5 \%$ \\
\hline
\end{tabular}

\subsection{Measurement model evaluation}

Perceived Role of Ethics and Social Responsibility (PRESOR) and Employee Engagement are considered as reflective measures with their respective indicator arrows pointing from a construct meaning the construct causes the measurement. Following the non-parametric quality criteria guide by Chin (2010), reflective measurement models should have factor loadings higher than 0.7, composite reliability should greater than 0.7, average variance extracted (AVE) should exceed 0.5 , and the Cronbach's alpha should be higher than 0.8 . Items that do not meet the quality criteria were eliminated in the scale refinement process. The results of the reflective measurement model are shown in Table 2 and Figure 2 respectively. 
Table 2

The results of reflective measurement model evaluation

\begin{tabular}{|c|c|c|c|c|c|c|}
\hline Constructs & Items & Loading & $\begin{array}{c}\text { Cronbach's } \\
\text { Alpha }\end{array}$ & rho_A & $\begin{array}{l}\text { Composite } \\
\text { Reliability }\end{array}$ & $\begin{array}{l}\text { Average Variance } \\
\text { Extracted (AVE) }\end{array}$ \\
\hline \multirow{4}{*}{ PRESOR } & PRESOR1 & 0.825 & 0.789 & 0.798 & 0.864 & 0.615 \\
\hline & PRESOR2 & 0.819 & & & & \\
\hline & PRESOR3 & 0.785 & & & & \\
\hline & PRESOR 4 & 0.699 & & & & \\
\hline \multirow[t]{6}{*}{ Employee Engagement } & Ee10 & 0.799 & 0.844 & 0.846 & 0.885 & 0.563 \\
\hline & Ee11 & 0.733 & & & & \\
\hline & Ee2 & 0.760 & & & & \\
\hline & Ee5 & 0.703 & & & & \\
\hline & Ee7 & 0.748 & & & & \\
\hline & Ee9 & 0.755 & & & & \\
\hline \multirow[t]{4}{*}{ Human Rights } & HR1 & 0.753 & 0.809 & 0.814 & 0.874 & 0.636 \\
\hline & HR2 & 0.798 & & & & \\
\hline & HR4 & 0.812 & & & & \\
\hline & HR5 & 0.824 & & & & \\
\hline \multirow[t]{5}{*}{ Healthy and Safety } & HS1 & 0.830 & 0.849 & 0.852 & 0.892 & 0.623 \\
\hline & HS2 & 0.769 & & & & \\
\hline & HS3 & 0.795 & & & & \\
\hline & HS4 & 0.770 & & & & \\
\hline & HS6 & 0.780 & & & & \\
\hline \multirow[t]{4}{*}{ Training and Development } & TD1 & 0.782 & 0.755 & 0.767 & 0.845 & 0.578 \\
\hline & TD2 & 0.683 & & & & \\
\hline & TD4 & 0.726 & & & & \\
\hline & TD5 & 0.841 & & & & \\
\hline \multirow[t]{4}{*}{ Work Diversity } & WD1 & 0.821 & 0.834 & 0.837 & 0.889 & 0.668 \\
\hline & WD3 & 0.833 & & & & \\
\hline & WD4 & 0.774 & & & & \\
\hline & WD5 & 0.840 & & & & \\
\hline \multirow[t]{7}{*}{ Work-Life Balance } & WLB2 & 0.710 & 0.875 & 0.879 & 0.903 & 0.573 \\
\hline & WLB3 & 0.822 & & & & \\
\hline & WLB4 & 0.675 & & & & \\
\hline & WLB5 & 0.738 & & & & \\
\hline & WLB6 & 0.764 & & & & \\
\hline & WLB7 & 0.761 & & & & \\
\hline & WLB8 & 0.817 & & & & \\
\hline
\end{tabular}




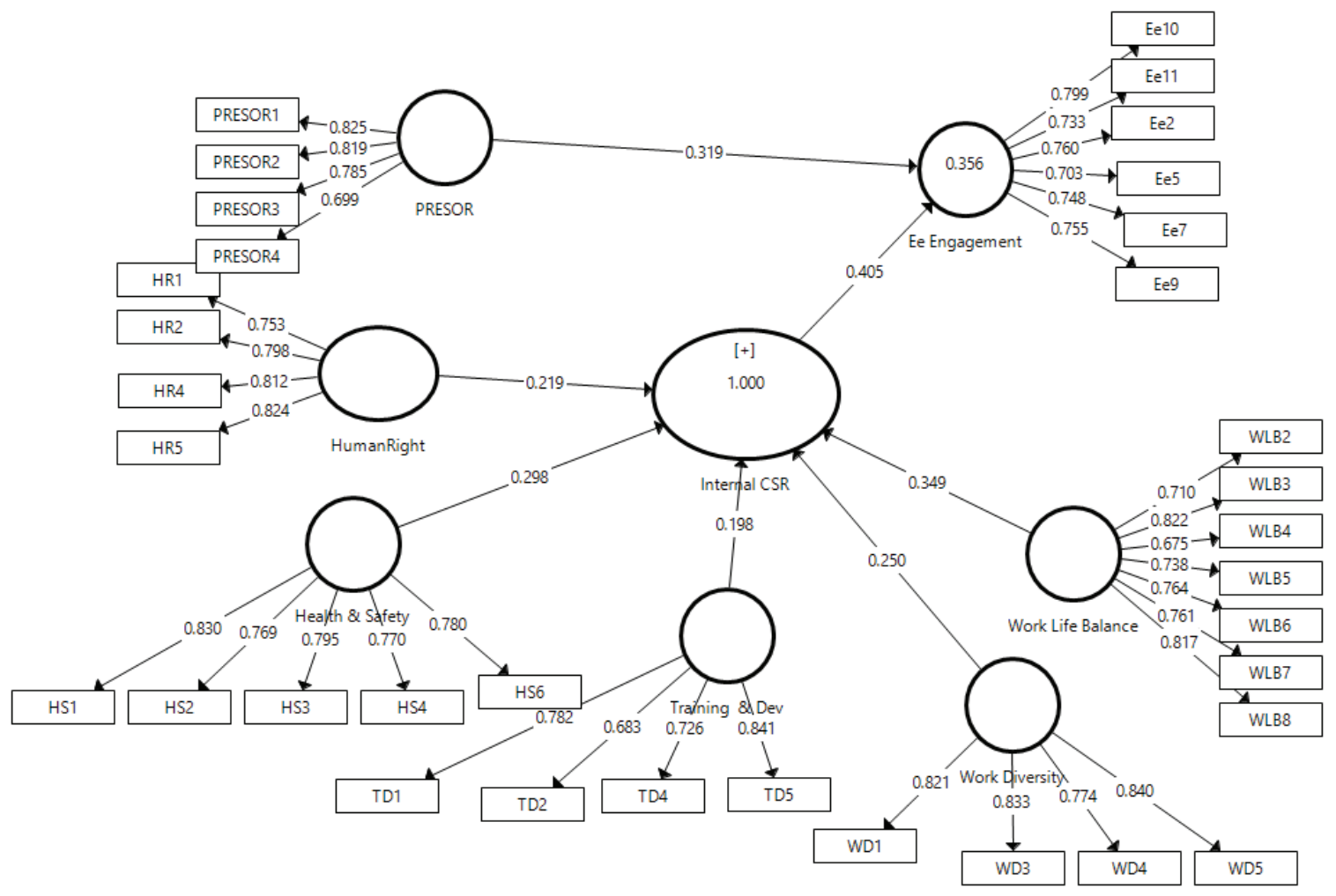

Figure 2. Measurement Model Evaluation

Table 3 illustrates the discriminant validity assessment. Discriminant validity is assessed using Henseler's heterotrait-monotrait (HTMT) (2015) criterion, which imposes more a stringent assessment compared to the earlier Fornell and Larcker (1981) criteria. The HTMT criterion suggests that all constructs are distinctively different at HTMT0.90 thresholds (Henseler, Ringle, \& Sarstedt, 2015). The discriminant validity results reveal that all the constructs studied are distinctively different at HTMT0.90. Tables 2 and 3 depict the assessment for the firstorder reflective measurement model.

Table 3

\section{HTMT Discriminant Validity criteria}

\begin{tabular}{lcccccc}
\hline & $\begin{array}{c}\text { Employee } \\
\text { Engagement }\end{array}$ & HS & HR & PRESOR & TD & $\begin{array}{c}\text { Work } \\
\text { Diversity }\end{array} \begin{array}{c}\text { Work Life } \\
\text { Balance }\end{array}$ \\
\hline Employee Engagement & & & & & & \\
HS & 0.512 & & & & \\
HR & 0.486 & 0.636 & & & \\
PRESOR & 0.557 & 0.433 & 0.349 & & & \\
TD & 0.486 & 0.727 & 0.501 & 0.453 & & 0.586 \\
WD & 0.464 & 0.637 & 0.665 & 0.328 & 0.599 & 0.49 \\
WLB & 0.406 & 0.435 & 0.414 & 0.185 & \\
\hline
\end{tabular}

Criteria: Discriminant validity is established at HTMT0.90 
Internal CSR is a type-II reflectiveformative construct where the first-order construct is a reflective model while the second-order construct is a formative model, as explained by Becker, Klein and Wetzels (2012). Hence, the quality criteria for the reflective model apply to the first-order model, and the quality criteria for the formative model are relevant for the secondorder model. The first-order constructs, namely Human Rights, Health and Safety, Training and Development, Work Diversity and Work-Life Balance, fulfilled the reflective model quality criteria as shown in Table 2. The formative model follows a different set of quality criteria that entail the convergent validity assessment, collinearity assessment and significance and relevance of the formative indicator, as highlighted by Hair, Hult, Ringle and Sarstedt (2017).

The convergent validity results are shown in Table 4. The collinearity issue is assessed through the variance inflation factor (VIF), which has a value lower than 5 , indicating that multicollinearity is not an issue, as shown in Table 5. Another important quality criterion in evaluating a formative measurement model is its relevance, which is assessed through its outer weight via bootstrapping. The outer weight of the formative measurement model should be significantly different from zero utilizing the bootstrapping procedure. Table 6 depicts the bootstrapping results of using 1000 sub-samples. It indicates that the outer weights and path coefficient for each of the formative second-order constructs (Hair et al., 2011) are significantly related to Internal CSR. Tables 4, 5 and 6 show that all the quality criteria for the formative measurement model's second-order construct were met and so the analysis proceeds with the structural model evaluation.
Table 4

\section{Internal CSR Convergent Validity result of Second-Order Constructs of Formative Measurement Model}

\begin{tabular}{|c|c|c|}
\hline Construct/ Indicator & $\begin{array}{c}\text { Outer } \\
\text { Weight }\end{array}$ & $\begin{array}{c}\text { Path } \\
\text { Coefficient }\end{array}$ \\
\hline Human Rights & & 0.901 \\
\hline HR 1 & 0.284 & \\
\hline HR 2 & 0.296 & \\
\hline HR 3 & 0.311 & \\
\hline HR 4 & 0.214 & \\
\hline HR 5 & 0.288 & \\
\hline Health \& Safety & & 0.906 \\
\hline HS1 & 0.274 & \\
\hline HS 2 & 0.177 & \\
\hline HS 3 & 0.201 & \\
\hline HS 4 & 0.254 & \\
\hline HS 5 & 0.170 & \\
\hline HS 6 & 0.282 & \\
\hline Training \& Development & & 0.891 \\
\hline TD 1 & 0.254 & \\
\hline TD 2 & 0.198 & \\
\hline TD 3 & 0.296 & \\
\hline TD 4 & 0.277 & \\
\hline TD 5 & 0.384 & \\
\hline Work Diversity & & 0.833 \\
\hline WD 1 & 0.222 & \\
\hline WD 2 & 0.301 & \\
\hline WD 3 & 0.195 & \\
\hline WD 4 & 0.259 & \\
\hline WD 5 & 0.348 & \\
\hline Work Life Balance & & 0.931 \\
\hline WLB1 & 0.146 & \\
\hline WLB 2 & 0.190 & \\
\hline WLB 3 & 0.196 & \\
\hline WLB 4 & 0.174 & \\
\hline WLB 5 & 0.151 & \\
\hline WLB 6 & 0.207 & \\
\hline WLB 7 & 0.154 & \\
\hline WLB 8 & 0.149 & \\
\hline
\end{tabular}


Table 5

Internal CSR Variance Inflation Factor (VIF) of Second-Order Constructs of Formative Measurement Model

\begin{tabular}{lc}
\hline Internal CSR & VIF \\
\hline Health and Safety & 1.967 \\
Human Rights & 1.632 \\
Training and Development & 1.721 \\
Work Diversity & 1.896 \\
Work-Life Balance & 1.428 \\
\hline
\end{tabular}

Table 6

Internal CSR Significance and Relevance of Second-Order Constructs of Formative Measurement Model

\begin{tabular}{lcccc}
\hline Formative indicators & Beta & Standard Error & $\boldsymbol{t}$-value & p value \\
\hline Health and Safety -> Internal CSR & 0.297 & 0.018 & 16.226 & 0.000 \\
Human Rights -> Internal CSR & 0.219 & 0.017 & 12.816 & 0.000 \\
Training and Development -> Internal CSR & 0.198 & 0.018 & 11.152 & 0.000 \\
Work Diversity -> Internal CSR & 0.250 & 0.015 & 16.224 & 0.000 \\
Work-Life Balance -> Internal CSR & 0.349 & 0.029 & 12.233 & 0.000 \\
\hline
\end{tabular}

\subsection{Structural model evaluation}

The structural model PLS evaluation includes four criteria. Firstly, the coefficients of determination $\left(\mathrm{R}^{2}\right)$ are used to indicate the variance accounted for by influencing variables; secondly, the VIFs assess the potential for the multicollinearity issue; thirdly, Stone-Geisser's, $Q^{2}$ (redundancy) is used as the indicator of predictive relevance; and lastly, $f$ is the effect size, which measures the change in the $\mathrm{R}^{2}$ value when a specified exogenous construct is omitted from the model to evaluate whether the omitted construct has a substantive impact on the endogenous construct. The results of the structural model evaluation can be found in Table 7 . Table 7 reports that multicollienearity is not a concern in this research as the VIF is below the threshold value of 5. Meanwhile, the $\mathrm{R}^{2}$ of the endogenous variable of employee engagement is 0.354 , showing that $35.4 \%$ of the variance in employee engagement is explained by Perceived Roles of Ethics and Social Responsibility (PRESOR) as well as Internal CSR.

Overall, the $Q^{2}$ value is 0.322 for Internal CSR and 0.184 for employee engagement, which are larger than 0 . These values reveal that both constructs possess predictive capacity with regard to employee engagement (Hair, Sarstedt, Hopkins \& Kuppelwieser, 2014). The results also demonstrated that both PRESOR and Internal CSR have a medium-sized effect on employee engagement, with $f=0.135$ and 0.222 respectively.

Table 7

\section{The results of the Structural Model Evaluation}

\begin{tabular}{lccccc}
\hline Construct & VIF & $\mathbf{R}^{2}$ & $\mathbf{Q}^{2}$ & $\boldsymbol{f}$ & Effect size \\
\hline PRESOR & 1.142 & & & 0.135 & Medium \\
Internal CSR & 1.204 & & 0.322 & 0.222 & Medium \\
Employee Engagement & & 0.354 & 0.184 & & \\
\hline
\end{tabular}




\section{$7 \cdot 4$ Hypotheses testing}

The overall sample of 212 responses was used to test the hypotheses in the basic research framework, namely $\mathrm{H} 1$ and $\mathrm{H} 2$. Chin (2010) and Lohmöeller (1989) confirmed any hypothesis for which the respective path coefficient was greater than 0.1 and significant at $p<0.05$. The results in Table 8 show that $\mathrm{H} 1$ is significant with a path coefficient of $0.319, p=0.00$ and $t$ value above 1.96. Similarly, H2 is significant with a path coefficient of $0.405, p$ value $=0.000$ and $t$ value of 5.857, even higher than 1.96. The bootstrapping results of the hypotheses testing are shown in Figure 3.

Table 8

\section{The significance of the path coefficients}

\begin{tabular}{lccccc}
\hline Hypothesis & Beta & Standard Error & t Value & p Value & Decision \\
\hline H1: PRESOR $\Rightarrow$ Employee Engagement & 0.319 & 0.065 & 4.890 & 0.000 & Significant \\
H2: Internal CSR $\Rightarrow$ Employee Engagement & 0.405 & 0.069 & 5.857 & 0.000 & Significant \\
\hline
\end{tabular}

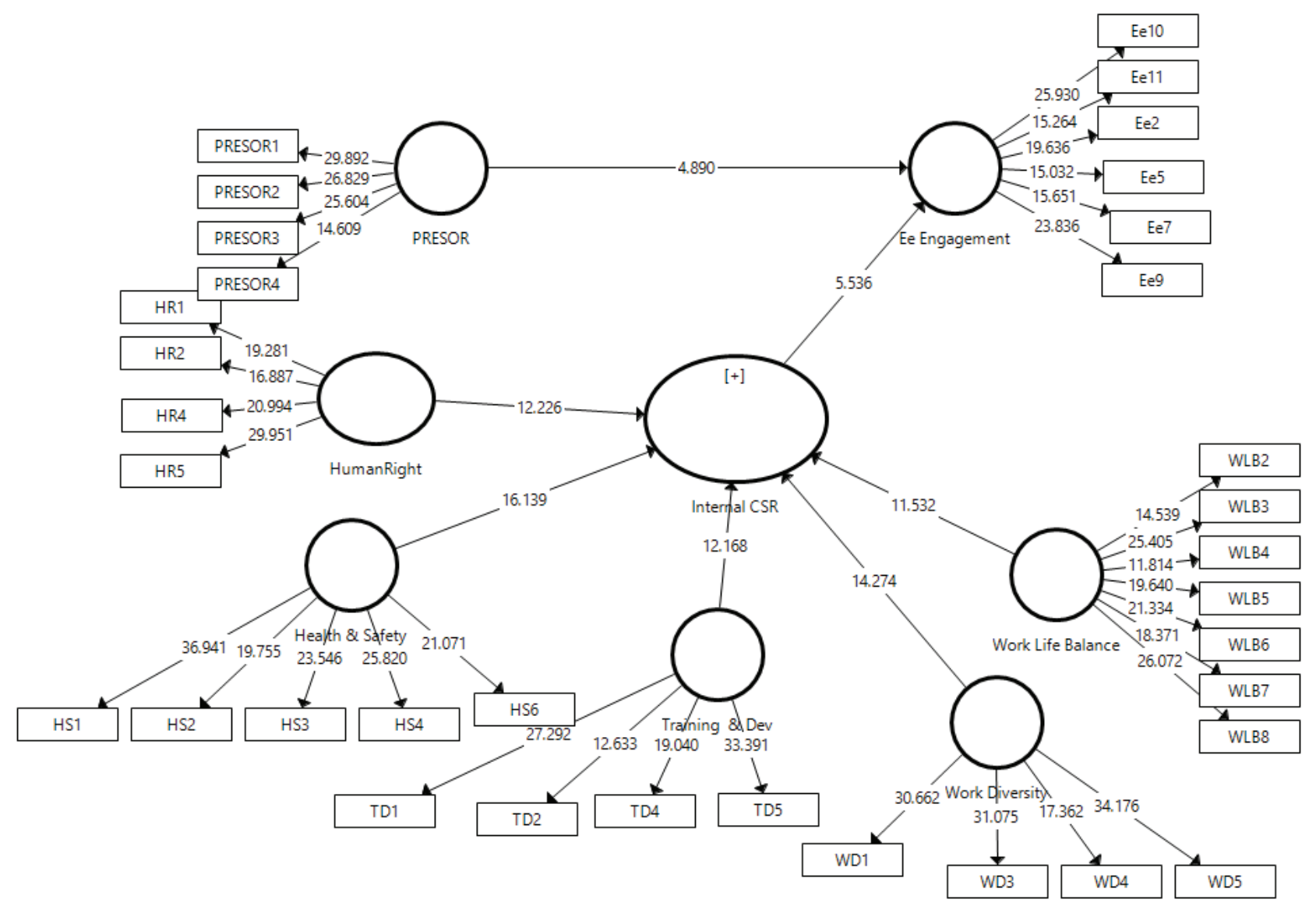

Figure 3. Structural Model Evaluation

This research also aims to investigate the relationships between the constructs of the research framework proposed across two subsamples in order to complement the understanding of the impact of ethics and social responsibility among the academics. In line with the guidelines 
proposed by Henseler, Ringle and Sarstedt (2016) and Matthews (2017) for the application of PLS, the MICOM procedure is performed to test measurement invariance. Three hierarchically interrelated steps of the MICOM procedure are carried out: configural invariance, compositional invariance, and equality of composite mean values and variances. Step 1 was carried out during the survey development whereby the meaning of indicators measuring specific constructs in the model was carefully inserted. Configural invariance was further addressed by identical data treatment and algorithm setting in both the nonmarried and married samples.

Step 2 of the MICOM procedure aims to assess equality in composite scores across the two sub-samples (Dijkstra \& Henseler, 2011). Permutation tests are conducted to statistically assess whether compositional invariance is present. Henseler et al. (2016) pointed out that permutation tests are nonparametric. They further explained that in each permutation run, the correlations between the composite scores using the weights obtained from the first group are computed against the composite scores using the weights acquired from the second group (Henseler et al., 2016). The results in Table 9 show that compositional invariance was demonstrated for all the constructs in the research framework. This is evident based on the original correlation being equal to or greater than $5.00 \%$ quantile correlations (shown in the $5.00 \%$ column).

Table 9

Results of Step 2 of the MICOM procedure

\begin{tabular}{lcccc}
\hline & Original Correlation & Correlation Permutation Mean & $\mathbf{5 . 0 0 \%}$ & Permutation p-Values \\
\hline Employee Engagement & 0.995 & 0.995 & 0.989 & 0.342 \\
Internal CSR & 0.998 & 0.998 & 0.995 & 0.630 \\
PRESOR & 0.997 & 0.996 & 0.989 & 0.500 \\
\hline
\end{tabular}

The next step, i.e., Step 3 of the MICOM procedure, is carried out to assess the composites' (constructs) equality of mean values and variances across the two groups of non-married and married academics. When establishing invariance, the mean original difference and variance original difference must fall within the $95 \%$ confidence interval. This is assessed by comparing the mean original difference and variance original difference to the lower $(2.5 \%)$ and upper (97.5\%) boundaries. According to Henseler et al. (2016), full measurement invariance for the composites is established when all the constructs must fall within the $95 \%$ confidence interval. However, note that in Table 11 the variance original difference value for all the constructs does not fall within the $95 \%$ confidence interval. The first portion of Step 3, as shown in Table 10 , indicated partial invariance for Employee Engagement, Internal CSR and Perceived Roles of Ethics and Social Responsibility. However, all the constructs did not meet the guidelines in Step 3 for establishing full invariance. Therefore, only partial invariance is confirmed for all the constructs, as illustrated in Tables 10 and 11 . Due to the full measurement of invariance not being established, the two subsamples cannot be subsequently analysed using the pooled data. Therefore, the analysis did not go on to determine if the path coefficients for the two subsamples are significantly different. 
Table 10

Results of Step 3 of the MICOM procedure - Part I

\begin{tabular}{lccc}
\hline & $\begin{array}{c}\text { Mean - Original Difference } \\
\text { ( Non-Married - Married ) }\end{array}$ & $\mathbf{2 , 5 0 \%}$ & $\mathbf{9 7 , 5 0 \%}$ \\
\hline Employee Engagement & 0,459 & $-0,472$ & 0,523 \\
Internal CSR & 0,296 & $-0,431$ & 0,445 \\
PRESOR & 0,131 & $-0,407$ & 0,406 \\
\hline
\end{tabular}

Table 11

Results of Step 3 of the MICOM procedure - Part II

\begin{tabular}{lccc}
\hline & $\begin{array}{c}\text { Variance - Original Difference } \\
\text { ( Non-Married - Married ) }\end{array}$ & $\mathbf{2 , 5 0 \%}$ & $\mathbf{9 7 , 5 0 \%}$ \\
\hline Employee Engagement & $-0,711$ & 0,001 & $-0,295$ \\
Internal CSR & $-0,448$ & $-0,008$ & $-0,252$ \\
PRESOR & $-0,543$ & $-0,002$ & $-0,258$ \\
\hline
\end{tabular}

With reference to the permutation test results, it is concluded that the measurement invariance between the two subsamples is not established. This result indicates that there are no significant differences between non-married and married academics in terms of the impact of ethics and social responsibility on employee engagement. Therefore, it is concluded that $\mathrm{H} 3$ and $\mathrm{H} 4$ as not significant.

\section{Conclusion and Discussions}

Overall, the findings of this research suggest that PRESOR, Internal CSR and Employee Engagement are meaningful constructs that warrant future research in the non-business setting. $\mathrm{H} 1$ and $\mathrm{H} 2$ are supported with beta $(\beta)$ values of 0.319 and 0.405 , and a $\mathrm{p}$ value $=0.000$ $<0.005$, respectively. However, H3 and H4 are not supported as only partial invariance was confirmed for all the constructs. The detailed results obtained help to paint a bigger picture of the role of social responsibility in academics' engagement in higher education institutions.

Firstly, significant relationships were established between both PRESOR and Internal CSR and Employee Engagement. The results indicate that the presence of PRESOR with the element of ethics and social responsibility is among the antecedents of employee engagement. The results provide the insight that higher education intuitions that do good will be repaid accordingly. This result is consistent with the research conducted in a business setting by Low and Ramayah (2016), in which PRESOR had an impact on Small and Medium-Sized Enterprises' (SMEs') employees. This leads to the supposition that PRESOR also plays a role in the non-business setting. As such, if higher education institutions plan to incorporate a wider range of socially responsible practices in the hope of having engaged academics, it is highly likely that this will yield a positive outcome.

Secondly, the result suggested a positive significant relationship between Internal CSR and Employee Engagement among the academics in the higher education institutions. This finding further reinforces Social Exchange Theory. The study defined employee engagement as a range of positive employee consequences obtained from job satisfaction, organisational commitment towards organisational citizenship behaviour (Kompaso \& Sridevi, 2010) and the existence of Internal CSR practices that take care of employees' welfare, which are appreciated through increased 
positive employee output. The underlying principle is the reciprocity between the higher education institution and its academics. Hence, when they are valued by the employer, there is a magnification effect that translates into higher job satisfaction, increased employee commitment and greater organisational citizenship behaviour. As highlighted by the research objective, enhanced employee engagement is highly sought in many organisations. In this context, higher education institutions are encouraged to carry out their social responsibility not only to educate the future generation by moulding a workforce ready for the future but also to display a sense of ethics towards the academics that are crucial capital in the education sector.

Thirdly, Hypotheses 3 and 4 are not supported, which indicates that there is no difference between non-married and married respondents in higher education institutions. The life course perspective does not have any significant implication in the context of ethics and social responsibility and higher education institutions. The nature of academics' job requirements offers a valid explanation for the findings. Academics can handle their work and personal responsibilities at different stages of their life that do not interfere with their work as academics. Subramaniam and Selvaratnam (2010) found that in some of the public sector, the private sector, and universities, family-friendly policies such as flexible working hours are available for employees. In this vein, the presence of Internal CSR practices does not seem to affect employee outcomes, such as employee engagement.

Lastly, despite the two hypotheses developed to test the different groups of academics being insignificant, the finding of this research supported the benefit of executing Internal CSR practices in higher education institutions. The finding contributes by providing empirical and statistical evidence that the presence of Internal CSR could mitigate the negative effect on employee engagement. This finding could further add to the existing literature on the positive influence of Internal CSR on employee engagement in the education sector when Internal CSR has already been embraced.

\section{I Theoretical and managerial implications}

The examination of the ethics and social responsibility element in the education sector implies that Social Exchange Theory stands in a non-business setting. The essence of reciprocity of Social Exchange Theory is observed through the significant effect of PRESOR and Internal CSR practices on employee engagement. This means that when employees are appreciated by organisations through efforts to take care of their well-being, they tend to be more engaged and committed to their jobs. An engaged and committed workforce is the core contributor to any organisation's performance and success. However, if the practices are already in place due to the nature of the profession, an enhanced effect on employee engagement would be unlikely. Hence, the findings of the study add value to the existing body of knowledge by providing more insights into the existence of practices and divergent expectations from both employers and employees.

In term of the managerial implication, it is recommended that administrators of higher education institutions use a different set of approaches to get their academics to be more engaged, apart from adopting Internal CSR practices. Recent research by Cadez, Dimovski and Zaman (2017) proposed the use of different performance evaluations to increase academics' engagement and therefore improve teaching quality. It is proposed that administrators use the corroborated performance evaluation based on the function of individual motivations instead of the work environment, as in the research conducted by Edgar and Geare (2013) and Kallio and Kallio (2014). The conclusion is that despite the changing environment and implementation of new practices, the individual element remains a strong determinant in employee engagement. 
As such, administrators are advised to look into various aspects in multiple platforms to achieve the objective of having engaged academics to meet the overall organisational goal of a worldwide ranking.

\section{Limitations and Directions for Future Research}

This research is not free from limitations. Due to the cost constraint, the study was confined to Peninsular Malaysia and it fails to generalise to the entire population. Moreover, this research only set out to understand the impact of PRESOR and Internal CSR activities on employee engagement. There could be other factors contributing to employee engagement other than ethics and social responsibilities.

It is recommended that future research is expanded to all higher education institutions in Malaysia by including universities located in Sabah and Sarawak. It is also proposed that a probability sampling method is used if the list of academics in the universities is available. Future research could also study the potential differences in the impact of ethics and social responsibilities between public and private universities. Moreover, the triangulation approach could be utilised to collect more in-depth information and perceptions of respondents on PRESOR and Internal CSR. In terms of employee engagement, future research could explore other organisational behaviour constructs such as perceived organisational support and leadership styles.

\section{Reference}

Adu-Febiri, F., \& Quinless, J. M. (2010). Workplace diversity and aboriginal people in Canada: Going beyond the managerial model. International Journal of Diversity in Organisations, Communities \& Nations, 10(4), 161-178.

Aguinis, H., \& Glavas, A. (2012). What we know and don't know about corporate social responsibility: A review and research agenda. Journal of management, 38(4), 932-968.

Akter, S., D'Ambra, J., \& Ray, P. (2011). Trustworthiness in health information services: an assessment of a hierarchical model with mediating and moderating effects using partial least squares (PLS). Journal of the Association for Information Science and Technology, 62(1), 100-116.

Axinn, C. N., Blair, M. E., Heorhiadi, A., \& Thach, S. V. (2004). Comparing Ethical Ideologies Across Cultures. Journal of business ethics, 54(2), 103-119.

Bauman, C. W., \& Skitka, L. J. (2012). Corporate social responsibility as a source of employee satisfaction. Research in Organizational Behavior, 32, 63-86.

Becker, J. M., Klein, K., \& Wetzels, M. (2012). Hierarchical latent variable models in PLS-SEM: guidelines for using reflective-formative type models. Long Range Planning, 45(5), 359-394.

Benson, G. S. (2006). Employee development, commitment and intention to turnover: A test of 'employability' policies in action. Human Resource Management Journal, 16(2), 173-192.

Bochenek, M., Kingston-Mann, E., \& Sieber, T. (2002). Achieving against the odds: How academics become teachers of diverse students. Teaching Sociology, 3O(1), 122.

Boddy, C. R. (2011). The corporate psychopaths' theory of the global financial crisis. Journal of Business Ethics, 102(2), 255-259.

Blau, P.M. (1964). Exchange and power in social life. New York: Routledge.

Cadez, S., Dimovski, V., \& Groff, M. Z. (2017). Research, teaching and performance evaluation in academia: The salience of quality. Studies in Higher Education, 42(8), 1455-1473. 
Carroll, A. B. (1999). Corporate social responsibility: Evolution of a definitional construct. Business \& society, 38(3), 268-295.

Charkham, J. (1994). Keeping good company: A study of corporate governance in five countries. Claredon: Oxford.

Chin, W. W. (2010). How to write up and report PLS analyses. In V. E. Vinzi, W.W. Chin, J. Henseler, \& H. Wang (Ed.), Handbook of partial least squares (pp. 655-690). Berlin: Springer.

Churchill, L. R. (1982). The teaching of ethics and moral values in teaching: Some contemporary confusions. The journal of higher education, 53(3), 296-306.

Clarkson, M. B. E. (1995). A Stakeholder Framework for Analyzing and Evaluating Corporate Social Performance. Academy of Management Review, 2O(1), 92-117.

Collier, J., \& Esteban, R. (2007). Corporate social responsibility and employee commitment. Business ethics: A European review, 16(1), 19-33.

Creswell, J. W., \& Creswell, J. D. (2017). Research design: Qualitative, quantitative, and mixed methods approaches. Los Angeles: Sage publications.

Crowther, D., \& Seifi, S. (Eds.). (2018). Redefining corporate social responsibility. United Kingdom: Emerald Group Publishing.

Dijkstra, T. K., \& Henseler, J. (2011). Linear indices in nonlinear structural equation models: Best fitting proper indices and other composites. Quality \& Quantity, 45(6), 1505.

Dögl, C., \& Holtbrügge, D. (2014). Corporate environmental responsibility, employer reputation and employee commitment: An empirical study in developed and emerging economies. The International Journal of Human Resource Management, 25(12), 1739-1762.
Eberl, M. (2010). An application of PLS in multi-group analysis: The need for differentiated corporate-level marketing in the mobile communications industry. In V. E. Vinzi, W.W. Chin, J. Henseler, \& H. Wang (Ed.), Handbook of partial least squares (pp. 487-514). Berlin: Springer.

Edgar, F., \& Geare, A. (2013). Factors influencing university research performance. Studies in Higher Education, 38(5), 774-792.

El Akremi, A., Gond, J. P., Swaen, V., Roeck, K., de, \& Igalens, J. (2015). How do employees perceive corporate responsibility? Development and validation of a multidimensional corporate stakeholder responsibility scale. Journal of Management, 44(2), 619-657.

Elango, B., Paul, K., Kundu, S.K., \& Paudel, S.K. (2010). Organizational ethics, individual ethics, and ethical intentions in international decision making. Journal of Business Ethics, 97(4), 543-561.

Elder, G. H., Jr. (1985). Life course dynamics: Trajectories and transitions 1968-1980. New York: Cornell University Press.

Enehaug, H., Helmersen, M., \& Mamelund, S. E. (2016). Individual and organizational well-being when workplace conflicts are on the agenda. A mixed methods study. Nordic Journal of Working Life Studies, 6(1). 83-104.

Farooq, O., Payaud, M., Merunka, D., \& Valette-Florence, P. (2014). The impact of corporate social responsibility on organizational commitment: Exploring multiple mediation mechanisms. Journal of Business Ethics, 125(4), 563-580.

Faul, F., Erdfelder, E., Lang, A. G., \& Buchner, A. (2009). Statistical power analyses using $G^{*}$ Power 3.1: Tests for correlation and regression analyses. Behaviour research methods, 41(4), 11491160. 
Faul, F., Erdfelder, E., Lang, A. G., \& Buchner, A. (2007). G* Power 3: A flexible statistical power analysis program for the social, behavioural, and biomedical sciences. Behaviour research methods, 39(2), 175-191.

Fornell, C., \& Lacker, D. F. (1981). Evaluating structural equation modeling for travel behaviour research. Transportation research part B, University of Michigan, 37, 1-25.

Freeman, R. E. (1984). Strategic management: $A$ stakeholder approach. Boston: Pitman/ Ballinger.

Gefen, D., Rigdon, E. E., \& Straub, D. (2011). Editor's comments: an update and extension to SEM guidelines for administrative and social science research. MIS Quarterly, 35(2), 3-14.

Gibbins, J. D., \& MacMahon, K. (2015). Workplace safety and health for the veterinary health care team. Veterinary Clinics: Small animal practice, 45(2), 409-426.

Grivastava, S., \& Kleiner, B. (2015). Managing Cultural Diversity in the Workplace. Journal of International Diversity, 2015(1), 30.

Gupta, N., \& Sharma, V. (2016). The relationship between corporate social responsibility and employee engagement and its linkage to organizational performance: A conceptual model. IUP Journal of Organizational Behavior, 15(3), 59-75.

Hair, J. F., Ringle, C. M., \& Sarstedt, M. (2011). PLS-SEM: Indeed a silver bullet. Journal of Marketing theory and Practice, 19(2), 139-152.

Hair, J. F., Jr., Sarstedt, M., Hopkins, L., \& G. Kuppelwieser, V. (2014). Partial least squares structural equation modeling (PLS-SEM): An emerging tool in business research. European Business Review, 26(2), 106-121.

Hair, J. F. Jr., Hult, G. T. M., Ringle, C., \& Sarstedt, M. (2017). A primer on partial least squares structural equation modeling (PLS-SEM). Los Angeles: Sage Publications.

Halpin, R., Curtis, P., \& Halpin, M. (2015). Assessing participant performance in online professional development training programs. Procedia-Social and Behavioral Sciences, 174, 186-193.

Henseler, J. (2007). A new and simple approach to multi-group analysis in partial least squares path modeling. Retrieved from https://core.ac.uk/ download/pdf/31147178.pdf

Henseler, J., Ringle, C. M., \& Sarstedt, M. (2015). A new criterion for assessing discriminant validity in variance-based structural equation modeling. Journal of the academy of marketing science, 43(1), 115-135.

Henseler, J., Ringle, C. M., \& Sarstedt, M. (2016). Testing measurement invariance of composites using partial least squares. International Marketing Review, 33(3), 405-431.

Henseler, J., Ringle, C. M., \& Sinkovics, R. R. (2009). The use of partial least squares path modeling in international marketing. Advances in International Marketing, 20, 277-319.

Hofman, P. S., \& Newman, A. (2014). The impact of perceived corporate social responsibility on organizational commitment and the moderating role of collectivism and masculinity: Evidence from China. The International Journal of Human Resource Management, 25(5), 631-652.

Hortyn, H. (2019). How looking beyond profit and being socially responsible can benefit your business? Elite Business. Retrieved from http:// elitebusinessmagazine.co.uk/analysis/item/ how-looking-beyond-profit-and-being-sociallyresponsible-can-benefit-your-business

Jing, L. (2008). Faculty's job stress and performance in the undergraduate education assessment in China: A mixed-methods study. Educational Research and Reviews, 3(9), 294. 
Joscelyne, A., Knuckey, S., Satterthwaite, M. L., Bryant, R. A., Li, M., Qian, M., \& Brown, A. D. (2015). Mental health functioning in the human rights field: Findings from an international internet-based survey. PloS one, 10(12).

Kaliannan, M., Perumal, K., \& Dorasamy, M. (2016). Developing a work-life balance model towards improving job satisfaction among medical doctors across different generations. The Journal of Developing Areas, 50(5), 343-351.

Kallio, K. M., \& Kallio, T. J. (2014). Managementby-results and performance measurement in universities-implications for work motivation. Studies in Higher Education, 39(4), 574-589.

Kleinhans, K., Chakradhar, K., Muller, S., \& Waddill, P. (2015). Multigenerational perceptions of the academic work environment in higher education in the United States. Higher Education, 70(1), 89-103.

Kompaso, S. M., \& Sridevi, M. S. (2010). Employee engagement: The key to improving performance. International journal of business and management, 5(12), 89-96.

Kunyk, D., Craig-Broadwith, M., Morris, H., Diaz, R., Reisdorfer, E., \& Wang, J. (2016). Employers' perceptions and attitudes toward the Canadian national standard on psychological health and safety in the workplace: A qualitative study. International journal of law and psychiatry, 44, 41-47.

Kuron, L. K., Lyons, S. T., Schweitzer, L., \& Ng, E. S. (2015). Millennials' work values: Differences across the school to work transition. Personnel Review, 44(6), 991-1009.

Lohmöller, J. B. (1989). Predictive vs. structural modeling: Pls vs. ml. In J.-B. Lohmöller, Latent Variable Path Modeling with Partial Least Squares (pp. 199-226). Heidelberg: PhysicaVerlag.
Low, M. P., \& Siegel, D. (2019). A bibliometric analysis of employee-centred corporate social responsibility research in the 2000s. Social Responsibility Journal. Retrieved from https:// www.emerald.com/insight/content/doi/10.1108/ SRJ-09-2018-0243/full/html

Low, M. P., \& Ramayah, T. (2016). Entrepreneurial orientation and social responsibility of small and medium sized Enterprises located in Selangor. Journal of Global Business and Social Entrepreneurship (GBSE), 2(3), 141-154.

Lozano, R. (2015). A holistic perspective on corporate sustainability drivers. Corporate social responsibility and environmental management, 22(1), 32-44.

Lozano, J. M., \& Prandi, M. (2005). Corporate social responsibility and human rights. In $\mathrm{R}$. Mullerat (Ed.). Corporate Social Responsibility: The Corporate Governance of the 21st century (Cap. 10, pp. 183-204). Netherland: Walters Kluwer.

Macey, W. H., \& Schneider, B. (2008). The meaning of employee engagement. Industrial and organizational Psychology, 1(1), 3-30.

Matthews, L. (2017). Applying multigroup analysis in PLS-SEM: A step-by-step process. In H. Latan, R. Noonan, Partial least squares path modeling: Basic concepts, methodological issues and applications (pp. 219-243). Los Angeles: Springer.

Ministry of Education, Malaysia (2017). Malaysia Education Statistics. Educational Data Sector Educational Planning and Research Division.

Mone, E. M., \& London, M. (2018). Employee engagement through effective performance management: A practical guide for managers. New York: Routledge.

Mory, L., Wirtz, B.W., \& Göttel, V. (2016). Corporate social responsibility strategies and their impact on employees' commitment. Journal of Strategy and Management, 9(2), 172-201. 
Mueller, K., Hattrup, K., Spiess, S. O., \& Lin$\mathrm{Hi}$, N. (2012). The effects of corporate social responsibility on employees' affective commitment: A cross-cultural investigation. Journal of Applied Psychology, 97(6), 1186.

Neacsu, N. A. (2015). Implementation of ISO 22000-a tool to increase business efficiency and customer satisfaction. A case study: SC Prodlacta Brasov. Bulletin of the Transilvania University of Brasov. Economic Sciences, 8(2), 105-110.

Podsakoff, P. M., MacKenzie, S. B., Lee, J. Y., \& Podsakoff, N. P. (2003). Common method biases in behavioral research: A critical review of the literature and recommended remedies. Journal of applied psychology, 88(5), 879-903. doi:10.1037/0021-9010.88.5.879

Polkowska, D. (2016). Work at home, home at work: Difficulties in achieving work-life balance in selected European countries. Polish Sociological Review, 194(2), 191-208.

Potdar, B., Guthrie, J., Gnoth, J., \& Garry, T. (2018). Yours ethically: The role of corporate social responsibility and employee engagement in shoplifting prevention. International Journal of Retail \& Distribution Management, 46(9), 835-849.

Reinartz, W., Haenlein, M., \& Henseler, J. (2009). An empirical comparison of the efficacy of covariance-based and variancebased SEM. International Journal of research in Marketing, 26(4), 332-344.

Robinson, D., Perryman, S., \& Hayday, S. (2004). The drivers of employee engagement. Brigton: Report-Institute for Employment Studies.

Roeck, K., de, \& Maon, F. (2016). Building the theoretical puzzle of employees' reactions to corporate social responsibility: An integrative conceptual framework and research agenda. Journal of Business Ethics, 149(3), 1-17.
Roeck, K., de, Marique, G., Stinglhamber, F., \& Swaen, V. (2014). Understanding employees' responses to corporate social responsibility: mediating roles of overall justice and organisational identification. The international journal of human resource management, 25(1), 91-112.

Russo, M., Shteigman, A., \& Carmeli, A. (2016). Workplace and family support and work-life balance: Implications for individual psychological availability and energy at work. The Journal of Positive Psychology, 11(2), 173-188.

Sekaran, U., \& Bougie, R. (2010). Research methods for business: A skill building approach. Chichester: Wiley.

Shafer, W. E., Fukukawa, K., \& Lee, G. M. (2007). Values and the perceived importance of ethics and social responsibility: The US versus China. Journal of Business Ethics, 70(3), 265-284.

Singhapakdi, A. (1999). Perceived importance of ethics and ethical decisions in marketing. Journal of Business Research, 45(1), 89-99.

Singhapakdi, A., Vitell, S. J., Rallapalli, K. C., \& Kraft, K. L. (1996). The perceived role of ethics and social responsibility: A scale development. Journal of Business Ethics, 15(11), 1131-1140.

Su, S., Baird, K., \& Schoch, H. (2015). Management control system effectiveness: The association between types of controls with employee organizational commitment across organisational life cycle stages. Pacific Accounting Review, 27(1), 28-50.

Subramaniam, G., \& Selvaratnam, D. P. (2010). Family friendly policies in Malaysia: where are we? Journal of International Business Research, 9(1), 43-55.

Turker, D. (2009a). How corporate social responsibility influences organizational commitment. Journal of Business Ethics, 89(2), 189-204. 
Turker, D. (2009b). Measuring corporate social responsibility: A scale development study. Journal of business ethics, 85(4), 411-427.

Valentine, S., \& Fleischman, G. (2008). Ethics programs, perceived corporate social responsibility and job satisfaction. Journal of business ethics, 77(2), 159-172.

Vance, R. J. (2006). Employee engagement and commitment: Guide to understanding measuring and increasing engagement in your organization. United States of America: SHRM Foundation.

Van der Klaauw, W. (1996). Female labour supply and marital status decisions: A life-cycle model. The Review of Economic Studies, 63(2), 199-235.

Verdeyen, V., Put, J. \& Buggenhout, B. V. (2004). A Social Stakeholder Model. International Journal of Social Welfare, 13(4), 325-331.

Vitell, S. J., Ramos, E., \& Nishihara, C. M. (2010). The role of ethics and social responsibility in organizational success: A Spanish perspective. Journal of Business Ethics, 91(4), 467-483.

Werther, W. B., \& Chandler, D. (2006). Strategic corporate social responsibility: Stakeholders in a global environment. London: Sage Publications.
Wheeler, D., \& Sillanpaa, M. (1997). The stakeholder corporation: The body shop blueprint for maximizing stakeholder value. London: Pitman.

White, B. (2008, November). The employee engagement equation in India. Presented by Blessing White and HR Anexi. [Online]. Retrieved from: www. blessingwhite. com

Wotruba, T. R. (1997). Industry self-regulation: A review and extension to a global setting. Journal of Public Policy \& Marketing, 16(1), 38-54.

Yin, J., Singhapakdi, A., \& Du, Y. (2016). Causes and moderators of corporate social responsibility in China: The influence of personal values and institutional logics. Asian Business \& Management, 15(3), 226-254.

Zhu, Q., Yin, H., Liu, J., \& Lai, K. H. (2014). How is employee perception of organizational efforts in corporate social responsibility related to their satisfaction and loyalty towards developing harmonious society in Chinese enterprises? Corporate Social Responsibility and Environmental Management, 21(1), 28-40. 


\section{Authors:}

1. Low Mei Peng, PhD (Organisational Behaviour), Universiti Tunku Abdul Rahman, Bandar Sungai Long, Malaysia. E-mail: lowmp@utar.edu.my

ORCID

(iD 0000-0002-3141-3081

\section{Contribution of each author}

1. Definition of research problem

2. Development of hypotheses or research questions (empirical studies )

3. Development of theoretical propositions ( theoretical Work )

4. Theoretical foundation/ Literature review

5. Definition of methodological procedures

6. Data collection

7. Statistical analysis

8. Analysis and interpretation of data

9. Critical revision of the manuscript

10. Manuscript Writing

11. Other 